\title{
Measuring Performance Using Educational Indicators
}

\author{
Hasan Abed Almohsen Almousawy** Prof.Abed Alsalam Lafta Saed / Prof.D \\ University of Baghdad/College of Administration \& Economics
}

DOI: $10.37648 / \mathrm{ijrssh} . v 10 \mathrm{i} 03.034$

Received: 18 ${ }^{\text {th }}$ June, 2020; Accepted: 31st July, 2020; Published: $19^{\text {th }}$ August,2020

\begin{abstract}
Education is a tool for change, construction and social development, and is the most successful means of achieving sustainable development and achieving human progress at all levels, and aims to build and prepare future generations to participate in building a future characterized by progress and permanence, thus seeking the Iraqi state to improve the educational sector through the application of modern standards in education. After decentralization became a global phenomenon in more than $80 \%$ of the world's countries, the Iraqi state began in 2016 to implement administrative decentralization, and local authorities were granted the powers to manage their affairs, including the administration of their educational institutions in accordance with the principle of administrative decentralization, and after four years of administrative decentralization and transfer of powers between the Iraqi Ministry of Education and local authorities, the study was conducted to measure the performance of educational institutions in order to ascertain whether the policy of decentralization had affected Negatively or positively on educational performance.

The research aims to measure educational performance before and after the transfer of powers from the federal government (Iraqi Ministry of Education) to local (provincial) governments using educational indicators. To achieve the objective of the research, educational data were collected and analysed, as well as the measurement and analysis of educational performance indicators during the first two phases of the application of the central system and extended between the academic year (2011-2012) and the academic year (2014-2015), while the second phase, which represents the phase of decentralization between the academic year (2015-2016) and the school year (2018-2019. The research community in all the directorates of education in the provinces of Iraq except the Kurdistan region and the following provinces (Kirkuk, Anbar, Salah al-Din, Ninawah) due to the lack of educational data in the ministry due to the security conditions witnessed, but the sample of the research consisted of eleven provinces, and The researcher calculates the scoring averages and the upper and lower limits of educational indicators in the provinces the field of research during the two periods (central and decentralized) and then comparing them using the ratio of method (Mann-Whitney) to determine the existence of moral differences between performance indicators in the two phases And determine which is better. The research concluded that the transition to a decentralized system and the transfer of powers between the Iraqi Ministry of Education and the provinces had a negative impact on educational performance.

Key words: Measuring Institutional Performance, Educational Indicators
\end{abstract}

\section{INTRODUCTION}

Education is the key to progress, development and sustainable development in order to build a prosperous future. The development and upgrading of the educational system requires the need to determine the reality of its achievements and failures over time, and its ability to achieve the desired goals and perform the desired roles and meet the required needs, so educational indicators have become one of the basic tools and one of the most important scientific methods used in the field

\section{INTERNATIONAL JOURNAL OF RESEARCH IN SOCIAL SCIENCES AND HUMANITIES}


of educational planning to determine the progress made by states in various educational fields and determine their educational needs, and to set policies, set goals and take measures related to them, as the indicators occupy an important place in providing a broad and integrated educational information base, and provide a clearer and realistic picture of The educational system and its objective judgment .

\section{THE CONCEPT OF MEASURING INSTITUTIONAL PERFORMANCE}

Performance measurement is an important part of the management process, using a set of qualitative and quantitative measures and indicators to determine the level of efficiency of organizations in using their available resources (Naseer,2005;26). measure the degree of success in achieving their objectives over a specified period of time, improve the quality of service delivery, detect and address shortcomings to avoid recurrence and occur in the future, and pay attention to the positive aspects of performance and use them in order to improve and improve the performance of the government apparatus (AlQahtani,2019;72). Performance measurement is an ongoing process of determining performance and tracking its level of development at all levels to ensure the efficiency and effectiveness of implementation, providing feedback and linking it to the strategic objectives of the government organ (Aguinis, 2009).

Table (1) Analysis of student/teacher rate in schools

\begin{tabular}{|c|c|c|c|c|c|c|c|c|c|c|}
\hline & school y & & & & & & & & lool year & \\
\hline Average & $19-18$ & $\begin{array}{l}-17 \\
18\end{array}$ & $17-16$ & $16-15$ & Average & $15-14$ & $14-13$ & $13-12$ & $12-11$ & Governorate \\
\hline 15.0 & 15.9 & 15.1 & 14.9 & 14.1 & 13.8 & 12.5 & 13.2 & 14.6 & 14.8 & 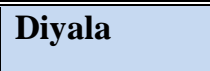 \\
\hline 20.5 & 20.8 & 20.3 & 20.7 & 20.0 & 18.3 & 18.7 & 18.0 & 18.3 & 18.0 & Baghdad \\
\hline 19.9 & 20.8 & 19.8 & 20.0 & 18.9 & 17.8 & 18.3 & 18.0 & 18.0 & 17.1 & Babylon \\
\hline 18.9 & 19.4 & 18.9 & 18.8 & 18.5 & 16.6 & 17.2 & 16.8 & 16.4 & 16.2 & Karbala \\
\hline
\end{tabular}

\section{THE CONCEPT OF EDUCATIONAL INDICATORS}

Performance indicators are tools used in the performance evaluation process, are considered as operational units of analysis and through which the data collected are identified to compare actual results with planned results and measure progress (Paige,2005:103). The indicators are defined as the set of comments, evidence, qualitative observations and quantitative observations describing the phenomenon or situation to be examined to reach a certain judgment according to agreed criteria (Al-Ammari,2019:9).Indicators have also been defined as qualitative or quantitative measures that determine over time the performance of functions and processes and the progress of results, and are measures of progress (unhcr, 2006:3).

\section{MEASURING AND ANALYZING EDUCATIONAL PERFORMANCE INDICATORS BEFORE AND AFTER TRANSFER OF POWERS}

This research is intended to discuss and analyze educational performance indicators to show the extent to which the transfer of powers from the Federal Ministry (education) to local governments is affected by the irregular provincial law in Region No. 21 of 2008, which was implemented in 2016 in the Ministry of Education, transferring its powers to local governments.

\section{First: Analysis of student/teacher rate}

By noting the approved figures in table (1) of the index (student/teacher rate) in primary and secondary schools (government, private and religious) the following: 


\begin{tabular}{|c|c|c|c|c|c|c|c|c|c|c|}
\hline 20.0 & 20.3 & 20.0 & 20.1 & 19.7 & 19.0 & 19.2 & 18.9 & 19.0 & 18.7 & Najaf \\
\hline 17.3 & 17.5 & 17.2 & 17.5 & 16.8 & 15.2 & 16.1 & 15.3 & 15.1 & 14.3 & "Qadisiyah \\
\hline 22.4 & 23.7 & 22.4 & 22.3 & 21.3 & 19.9 & 20.9 & 19.6 & 20.1 & 19.0 & Mouthana \\
\hline 18.1 & 18.5 & 17.7 & 18.3 & 17.7 & 16.5 & 17.4 & 16.6 & 16.5 & 15.6 & Wasit \\
\hline 18.1 & 18.2 & 17.8 & 18.5 & 17.8 & 16.8 & 17.5 & 16.7 & 16.8 & 16.0 & Dhi Qar \\
\hline 19.2 & 21.7 & 19.6 & 18.6 & 16.6 & 15.6 & 16.2 & 15.9 & 15.8 & 14.7 & "Maysan \\
\hline 23.9 & 24.9 & 24.2 & 23.7 & 22.7 & 20.7 & 21.1 & 20.8 & 20.4 & 20.4 & Basra \\
\hline 19.4 & 20.2 & 19.4 & 19.4 & 18.6 & 17.3 & 17.7 & 17.2 & 17.4 & 16.8 & the average \\
\hline
\end{tabular}

Source: Prepared by the researcher based on the statistical tables of the Statistics Department in the General Directorate of

Educational Planning / Iraqi Ministry of Education

It is clear from the results of the Mann Whitney test that the $\mathrm{z}$ value is equal to (2.309-) and the level of significance equalto (0.021) so we accept the hypothesis that there are statistically significant differences in the student/teacher rate at the level of significance $(\alpha<0.05)$ between the central and administrative decentralization periods.

\section{Second: Student/school rate analysis}

By noting the approved figures in table (2) of the index (student/school rate) in primary and secondary schools (government, private and religious) the following:

Table (2) Student/School Rate Analysis in Schools

\begin{tabular}{|c|c|c|c|c|c|c|c|c|c|c|}
\hline \multirow[b]{2}{*}{ Average } & \multicolumn{4}{|c|}{ school year } & \multirow[b]{2}{*}{ Average } & \multicolumn{4}{|c|}{ school year } & \multirow[b]{2}{*}{ Governorate } \\
\hline & $19-18$ & $18-17$ & $17-16$ & $16-15$ & & $15-14$ & $14-13$ & $13-12$ & $12-11$ & \\
\hline 302.1 & 309.0 & 307.8 & 302.5 & 289.1 & 278.2 & 259.8 & 278.3 & 284.6 & 290.1 & Diyala \\
\hline 561.1 & 527.2 & 543.1 & 562.1 & 612.1 & 535.3 & 544.8 & 524.7 & 535.2 & 536.5 & Baghdad \\
\hline 448.4 & 453.5 & 450.3 & 450.4 & 439.2 & 418.3 & 425.7 & 419.5 & 420.8 & 407.2 & Babylon \\
\hline 457.5 & 458.0 & 458.8 & 453.8 & 459.3 & 425.4 & 439.8 & 424.2 & 421.1 & 416.4 & Karbala \\
\hline 427.9 & 421.0 & 429.1 & 434.8 & 426.4 & 424.6 & 428.5 & 421.2 & 429.8 & 418.9 & Najaf \\
\hline 349.9 & 347.0 & 347.0 & 351.6 & 353.9 & 336.0 & 345.7 & 334.8 & 335.2 & 328.2 & Qadisiyah \\
\hline 347.8 & 361.6 & 348.3 & 346.0 & 335.2 & 318.5 & 331.6 & 320.8 & 317.0 & 304.8 & Mouthana \\
\hline
\end{tabular}




\begin{tabular}{|c|c|c|c|c|c|c|c|c|c|c|}
\hline 307.2 & 310.4 & 307.0 & 307.1 & 304.2 & 292.0 & 302.4 & 292.9 & 287.5 & 285.3 & Wasit \\
\hline 302.2 & 301.8 & 299.1 & 305.8 & 301.9 & 294.6 & 302.5 & 296.6 & 293.9 & 285.5 & Dhi Qar \\
\hline 367.0 & 403.9 & 373.6 & 363.2 & 327.2 & 319.2 & 329.3 & 326.9 & 317.2 & 303.3 & \begin{tabular}{|l} 
Maysan \\
\end{tabular} \\
\hline 415.0 & 407.6 & 415.8 & 420.4 & 416.2 & 414.1 & 416.7 & 414.7 & 412.2 & 412.9 & Basra \\
\hline 389.6 & 391.0 & 389.1 & 390.7 & 387.7 & 368.8 & 375.2 & 368.6 & 368.6 & 362.6 & the average \\
\hline
\end{tabular}

Source: Prepared by the researcher based on the statistical tables of the Statistics Department in the General Directorate of Educational Planning / Iraqi Ministry of Education

It is clear from the results of the Mann Whitney test that the $\mathrm{z}$ value is equal to (1.155-) and the level of significance equalto (0.248) so we accept the nihilistic hypothesis that there are no statistically significant differences in the student/school rate at a level of significance $(\alpha<0.05)$ between the central and administrative decentralization periods.

\section{Third: Student/class rate analysis}

By noting the approved figures in table (3) of the index (student/class rate) in primary and secondary schools (government, private and religious) the following:

Table (3) Student/class rate analysis in schools

\begin{tabular}{|c|c|c|c|c|c|c|c|c|c|c|}
\hline & school y & & & & & school & ear & & & \\
\hline Average & $19-18$ & $18-17$ & $17-16$ & $16-15$ & Average & $15-14$ & $14-13$ & $13-12$ & $12-11$ & Governorate \\
\hline 34.3 & 34.9 & 34.8 & 33.4 & 34.2 & 32.4 & 33.1 & 31.8 & 32.2 & 32.4 & Diyala \\
\hline 40.9 & 40.2 & 40.6 & 41.4 & 41.2 & 39.1 & 39.9 & 38.3 & 39.0 & 39.3 & Baghdad \\
\hline 40.2 & 40.2 & 40.0 & 40.7 & 40.1 & 38.1 & 39.4 & 38.5 & 38.1 & 36.3 & Babylon \\
\hline 38.3 & 38.2 & 38.3 & 38.1 & 38.7 & 37.0 & 37.5 & 37.1 & 36.7 & 36.6 & Karbala \\
\hline 36.1 & 36.1 & 36.3 & 36.1 & 36.1 & 35.5 & 35.7 & 35.1 & 35.9 & 35.4 & Najaf \\
\hline 36.8 & 36.8 & 36.8 & 37.0 & 36.5 & 34.4 & 35.5 & 34.6 & 34.2 & 33.5 & Qadisiyah \\
\hline 36.3 & 37.7 & 36.2 & 36.1 & 35.0 & 33.5 & 33.9 & 33.5 & 33.6 & 32.9 & Mouthana \\
\hline 32.6 & 32.8 & 32.5 & 32.9 & 32.1 & 31.7 & 32.1 & 31.9 & 31.4 & 31.3 & Wasit \\
\hline 33.2 & 33.5 & 32.5 & 31.8 & 35.0 & 34.2 & 34.8 & 34.6 & 34.0 & 33.3 & Dhi Qar \\
\hline 35.1 & 36.9 & 34.7 & 35.0 & 33.9 & 32.8 & 34.2 & 33.8 & 32.1 & 31.2 & Maysan \\
\hline
\end{tabular}




\begin{tabular}{|c|c|c|c|c|c|c|c|c|c|c|}
\hline 39.0 & 38.4 & 38.9 & 39.5 & 39.2 & 39.0 & 38.9 & 39.2 & 38.9 & 39.1 & Basra \\
\hline 36.6 & 36.9 & 36.5 & 36.5 & 36.5 & 35.2 & 35.9 & 35.3 & 35.1 & 34.7 & the average \\
\hline
\end{tabular}

Source: Prepared by the researcher based on the statistical tables of the Statistics Department in the General Directorate of Educational Planning / Iraqi Ministry of Education

It is clear from the results of the Mann Whitney test that the $\mathrm{z}$ value is equal to (1.443-) and the level of significance equalto (0.149) so we accept the nihilistic hypothesis that there are no statistically significant differences in the student/class rate at the level of significance $(\alpha<0.05)$ between the central and administrative decentralization periods.

Fourth: Analysis of the enrolment rate in the first grade of primary school

By noting the approved figures in table (4) for the index (first grade enrolment rate) in primary schools (government, private and religious) the following:

Table (4) Analysis of first grade

\begin{tabular}{|c|c|c|c|c|c|c|c|c|c|c|}
\hline & school y & & & & & school & ear & & & \\
\hline Average & $19-18$ & $18-17$ & $17-16$ & $16-15$ & Average & $15-14$ & $14-13$ & $13-12$ & $12-11$ & Governorate \\
\hline $99.6 \%$ & $99.6 \%$ & $99.6 \%$ & $99.4 \%$ & $99.6 \%$ & $99.5 \%$ & $99.5 \%$ & $99.3 \%$ & $99.6 \%$ & $99.6 \%$ & Diyala \\
\hline $98.2 \%$ & $98.0 \%$ & $98.2 \%$ & $98.1 \%$ & $98.3 \%$ & $98.2 \%$ & $98.4 \%$ & $98.1 \%$ & $98.2 \%$ & $98.0 \%$ & Baghdad \\
\hline $96.8 \%$ & $97.1 \%$ & $97.0 \%$ & $96.8 \%$ & $96.5 \%$ & $98.3 \%$ & $98.2 \%$ & $98.4 \%$ & $98.2 \%$ & $98.4 \%$ & Babylon \\
\hline $98.2 \%$ & $98.2 \%$ & $98.3 \%$ & $98.1 \%$ & $98.1 \%$ & $98.5 \%$ & $98.6 \%$ & $98.6 \%$ & $98.4 \%$ & $98.3 \%$ & Karbala \\
\hline $97.9 \%$ & $97.9 \%$ & $97.8 \%$ & $98.0 \%$ & $97.9 \%$ & $98.3 \%$ & $98.5 \%$ & $98.4 \%$ & $98.2 \%$ & $98.0 \%$ & Najaf \\
\hline $98.2 \%$ & $98.8 \%$ & $98.2 \%$ & $98.5 \%$ & $97.4 \%$ & $98.5 \%$ & $98.5 \%$ & $98.5 \%$ & $98.9 \%$ & $98.0 \%$ & Qadisiyah \\
\hline $98.7 \%$ & $99.0 \%$ & $99.1 \%$ & $98.2 \%$ & $98.3 \%$ & $98.8 \%$ & $99.0 \%$ & $98.8 \%$ & $99.0 \%$ & $98.5 \%$ & Mouthana \\
\hline $98.1 \%$ & $98.3 \%$ & $97.9 \%$ & $97.9 \%$ & $98.1 \%$ & $98.0 \%$ & $98.0 \%$ & $98.0 \%$ & $98.0 \%$ & $97.9 \%$ & Wasit \\
\hline $98.3 \%$ & $98.3 \%$ & $98.5 \%$ & $98.4 \%$ & $98.1 \%$ & $98.5 \%$ & $98.5 \%$ & $98.8 \%$ & $98.6 \%$ & $98.0 \%$ & Dhi Qar \\
\hline $97.9 \%$ & $98.6 \%$ & $98.2 \%$ & $97.4 \%$ & $97.4 \%$ & $98.7 \%$ & $98.7 \%$ & $98.6 \%$ & $98.6 \%$ & $99.1 \%$ & Maysan \\
\hline $98.2 \%$ & $98.3 \%$ & $98.0 \%$ & $98.2 \%$ & $98.4 \%$ & $98.2 \%$ & $98.4 \%$ & $98.4 \%$ & $98.0 \%$ & $98.0 \%$ & Basra \\
\hline
\end{tabular}




\begin{tabular}{|c|c|c|c|c|c|c|c|c|c|c|}
\hline $98.2 \%$ & $98.4 \%$ & $98.2 \%$ & $98.1 \%$ & $98.0 \%$ & $98.5 \%$ & $98.6 \%$ & $98.5 \%$ & $98.5 \%$ & $98.4 \%$ & the average \\
\hline
\end{tabular}

Source: Prepared by the researcher based on the statistical tables of the Statistics Department in the General Directorate of Educational Planning / Iraqi Ministry of Education

It is clear from the results of the Mann Whitney test that the $\mathrm{z}$ value is equal to (2.021-) and the level of significance equalto (0.043) so we accept the hypothesis that there are statistically significant differences in the first grade enrolment rate at the level of significance $(\alpha<0.05)$ between the central and administrative decentralization periods.

\section{Fifth: Leakage rate analysis}

By noting the approved figures in table (5) on the index (dropout rate) in primary and secondary schools (government, private and religious) we note the following:

Table (5) Analysis of leakage rate in schools

\begin{tabular}{|c|c|c|c|c|c|c|c|c|c|c|}
\hline & school y & & & & & school & ear & & & \\
\hline Average & $19-18$ & $18-17$ & $17-16$ & $16-15$ & Average & $15-14$ & $14-13$ & $13-12$ & $12-11$ & Governorate \\
\hline $1.1 \%$ & $0.8 \%$ & $0.9 \%$ & $1.1 \%$ & $1.6 \%$ & $1.0 \%$ & $0.9 \%$ & $1.2 \%$ & $1.0 \%$ & $1.0 \%$ & Diyala \\
\hline $2.6 \%$ & $2.3 \%$ & $2.2 \%$ & $2.4 \%$ & $3.3 \%$ & $2.3 \%$ & $2.2 \%$ & $2.3 \%$ & $2.3 \%$ & $2.5 \%$ & Baghdad \\
\hline $3.2 \%$ & $3.4 \%$ & $3.4 \%$ & $3.6 \%$ & $2.4 \%$ & $2.4 \%$ & $2.5 \%$ & $2.2 \%$ & $2.3 \%$ & $2.5 \%$ & Babylon \\
\hline $2.6 \%$ & $2.7 \%$ & $2.2 \%$ & $2.6 \%$ & $2.8 \%$ & $2.0 \%$ & $2.0 \%$ & $1.8 \%$ & $1.9 \%$ & $2.2 \%$ & Karbala \\
\hline $2.4 \%$ & $2.2 \%$ & $2.3 \%$ & $2.6 \%$ & $2.7 \%$ & $1.9 \%$ & $2.0 \%$ & $1.7 \%$ & $1.9 \%$ & $2.0 \%$ & Najaf \\
\hline $2.0 \%$ & $1.8 \%$ & $2.1 \%$ & $1.9 \%$ & $2.0 \%$ & $1.8 \%$ & $1.6 \%$ & $1.6 \%$ & $2.1 \%$ & $1.8 \%$ & Q Qadisiyah \\
\hline $2.5 \%$ & $2.0 \%$ & $1.9 \%$ & $2.3 \%$ & $3.7 \%$ & $1.7 \%$ & $2.1 \%$ & $1.5 \%$ & $1.5 \%$ & $1.7 \%$ & Mouthana \\
\hline $2.5 \%$ & $1.8 \%$ & $2.4 \%$ & $2.5 \%$ & $3.2 \%$ & $2.1 \%$ & $2.3 \%$ & $2.1 \%$ & $2.1 \%$ & $2.0 \%$ & Wasit \\
\hline $1.9 \%$ & $1.8 \%$ & $1.8 \%$ & $1.8 \%$ & $2.0 \%$ & $1.5 \%$ & $1.7 \%$ & $1.3 \%$ & $1.6 \%$ & $1.6 \%$ & Dhi Qar \\
\hline $2.5 \%$ & $1.7 \%$ & $2.1 \%$ & $2.5 \%$ & $3.6 \%$ & $1.5 \%$ & $1.4 \%$ & $1.4 \%$ & $1.3 \%$ & $1.9 \%$ & Maysan \\
\hline $1.7 \%$ & $1.8 \%$ & $2.0 \%$ & $2.0 \%$ & $0.9 \%$ & $1.9 \%$ & $1.7 \%$ & $1.7 \%$ & $2.2 \%$ & $1.9 \%$ & Basra \\
\hline $2.3 \%$ & $2.0 \%$ & $2.1 \%$ & $2.3 \%$ & $2.6 \%$ & $1.8 \%$ & $1.9 \%$ & $1.7 \%$ & $1.8 \%$ & $1.9 \%$ & the average \\
\hline
\end{tabular}

Source: Prepared by the researcher based on the statistical tables of the Statistics Department in the General Directorate of Educational Planning / Iraqi Ministry of Education 
1The results of the Mann Whitney test show that the $\mathrm{z}$ value is equal to (2.309-) and the level of significance equals (0.021) so we accept the hypothesis that there are statistically significant differences in the leakage rate at the indicative level $(\alpha<0.05)$ between the central and administrative decentralization periods.

\section{Sixthly: Analysis of the proportion of private schools}

By noting the approved figures in table (6) for the index (ratio of private schools) to the total elementary and secondary schools (government, private and religious) the following:

Table (6) Analysis of the proportion of private schools

\begin{tabular}{|c|c|c|c|c|c|c|c|c|c|c|}
\hline & school y & & & & & school & ear & & & \\
\hline Average & $19-18$ & $18-17$ & $17-16$ & $16-15$ & Average & $15-14$ & $14-13$ & $13-12$ & $12-11$ & Governorate \\
\hline $2.1 \%$ & $3.7 \%$ & $2.6 \%$ & $1.3 \%$ & $0.9 \%$ & $0.4 \%$ & $0.8 \%$ & $0.5 \%$ & $0.2 \%$ & $0.2 \%$ & Diyala \\
\hline $11.8 \%$ & $16.0 \%$ & $12.7 \%$ & $9.5 \%$ & $8.8 \%$ & $5.6 \%$ & $6.9 \%$ & $6.1 \%$ & $5.1 \%$ & $4.3 \%$ & Baghdad \\
\hline $4.1 \%$ & $5.9 \%$ & $4.6 \%$ & $3.3 \%$ & $2.6 \%$ & $1.6 \%$ & $2.3 \%$ & $2.1 \%$ & $1.2 \%$ & $0.8 \%$ & Babylon \\
\hline $7.3 \%$ & $9.3 \%$ & $7.5 \%$ & $6.3 \%$ & $6.0 \%$ & $4.0 \%$ & $4.9 \%$ & $4.6 \%$ & $3.7 \%$ & $2.9 \%$ & Karbala \\
\hline $12.7 \%$ & $15.7 \%$ & $13.9 \%$ & $10.9 \%$ & $10.1 \%$ & $5.1 \%$ & $8.3 \%$ & $6.4 \%$ & $3.6 \%$ & $2.1 \%$ & Najaf \\
\hline $7.6 \%$ & $10.0 \%$ & $8.4 \%$ & $6.9 \%$ & $5.3 \%$ & $4.4 \%$ & $5.5 \%$ & $5.4 \%$ & $3.9 \%$ & $3.0 \%$ & Qadisiyah \\
\hline $3.7 \%$ & $5.0 \%$ & $3.9 \%$ & $2.9 \%$ & $2.8 \%$ & $1.3 \%$ & $2.3 \%$ & $1.7 \%$ & $0.6 \%$ & $0.5 \%$ & Mouthana \\
\hline $2.9 \%$ & $4.2 \%$ & $3.0 \%$ & $2.4 \%$ & $2.2 \%$ & $1.2 \%$ & $1.6 \%$ & $1.3 \%$ & $1.1 \%$ & $0.8 \%$ & Wasit \\
\hline $8.7 \%$ & $11.0 \%$ & $10.1 \%$ & $7.1 \%$ & $6.5 \%$ & $4.4 \%$ & $5.3 \%$ & $4.4 \%$ & $4.1 \%$ & $3.6 \%$ & "Dhi Qar \\
\hline $2.8 \%$ & $3.0 \%$ & $2.9 \%$ & $2.8 \%$ & $2.5 \%$ & $1.9 \%$ & $2.6 \%$ & $2.4 \%$ & $1.9 \%$ & $0.9 \%$ & Maysan \\
\hline $19.0 \%$ & $22.5 \%$ & $20.2 \%$ & $17.2 \%$ & $16.1 \%$ & $11.8 \%$ & $13.8 \%$ & $12.5 \%$ & $11.0 \%$ & $9.9 \%$ & Basra \\
\hline $7.5 \%$ & $9.7 \%$ & $8.2 \%$ & $6.4 \%$ & $5.8 \%$ & $3.8 \%$ & $4.9 \%$ & $4.3 \%$ & $3.3 \%$ & $2.7 \%$ & the average \\
\hline
\end{tabular}

Source: Prepared by the researcher based on the statistical tables of the Statistics Department in the General Directorate of Educational Planning / Iraqi Ministry of Education 
It is clear from the results of the Mann Whitney test that the $\mathrm{z}$ value is equal to (2.309-) and the level of significance equalto (0.021) so we accept the hypothesis that there are statistically significant differences in the proportion of private schools at the level of significance $(\alpha<0.05)$ between the central and administrative decentralization periods.

\section{Seventh: Analysis of the percentage of students in private schools}

By noting the approved figures in table (7) on the index (ratio of students and private students) to the total elementary and secondary schools (government, private and religious) the following:

Table (7) Analysis of the proportion of students

\begin{tabular}{|c|c|c|c|c|c|c|c|c|c|c|}
\hline & school y & & & & & school & ear & & & \\
\hline Average & $19-18$ & $18-17$ & $17-16$ & $16-15$ & Average & $15-14$ & $14-13$ & $13-12$ & $12-11$ & Governorate \\
\hline $0.7 \%$ & $1.4 \%$ & $0.9 \%$ & $0.3 \%$ & $0.3 \%$ & $0.1 \%$ & $0.2 \%$ & $0.1 \%$ & $0.1 \%$ & $0.1 \%$ & $\overline{\text { Diyala }}$ \\
\hline $3.4 \%$ & $4.8 \%$ & $3.8 \%$ & $2.9 \%$ & $2.4 \%$ & $1.6 \%$ & $1.9 \%$ & $1.8 \%$ & $1.5 \%$ & $1.2 \%$ & Baghdad \\
\hline $1.8 \%$ & $2.6 \%$ & $2.0 \%$ & $1.5 \%$ & $1.1 \%$ & $0.5 \%$ & $0.9 \%$ & $0.7 \%$ & $0.4 \%$ & $0.2 \%$ & Babylon \\
\hline $3.8 \%$ & $4.9 \%$ & $4.2 \%$ & $3.4 \%$ & $2.8 \%$ & $1.5 \%$ & $2.1 \%$ & $1.8 \%$ & $1.3 \%$ & $1.0 \%$ & Karbala \\
\hline $7.6 \%$ & $9.7 \%$ & $8.4 \%$ & $6.7 \%$ & $5.6 \%$ & $3.2 \%$ & $4.8 \%$ & $4.0 \%$ & $1.9 \%$ & $2.1 \%$ & Najaf \\
\hline $2.4 \%$ & $3.1 \%$ & $2.7 \%$ & $2.2 \%$ & $1.7 \%$ & $1.3 \%$ & $1.6 \%$ & $1.5 \%$ & $1.2 \%$ & $0.9 \%$ & Qadisiyah \\
\hline $2.9 \%$ & $4.5 \%$ & $2.9 \%$ & $2.2 \%$ & $1.8 \%$ & $0.8 \%$ & $1.4 \%$ & $1.1 \%$ & $0.5 \%$ & $0.3 \%$ & Mouthana \\
\hline $1.2 \%$ & $1.9 \%$ & $1.2 \%$ & $0.9 \%$ & $0.9 \%$ & $0.5 \%$ & $0.7 \%$ & $0.6 \%$ & $0.5 \%$ & $0.3 \%$ & Wasit \\
\hline $3.6 \%$ & $4.9 \%$ & $3.9 \%$ & $3.0 \%$ & $2.5 \%$ & $1.7 \%$ & $2.2 \%$ & $1.9 \%$ & $1.6 \%$ & $1.3 \%$ & $\overline{\text { Dhi Qar }}$ \\
\hline $1.1 \%$ & $1.0 \%$ & $1.1 \%$ & $1.0 \%$ & $1.3 \%$ & $0.9 \%$ & $1.3 \%$ & $1.1 \%$ & $0.8 \%$ & $0.6 \%$ & Maysan \\
\hline $8.6 \%$ & $10.1 \%$ & $8.9 \%$ & $7.8 \%$ & $7.5 \%$ & $5.7 \%$ & $6.9 \%$ & $6.3 \%$ & $5.3 \%$ & $4.3 \%$ & Basra \\
\hline $3.4 \%$ & $4.5 \%$ & $3.6 \%$ & $2.9 \%$ & $2.5 \%$ & $1.6 \%$ & $2.2 \%$ & $1.9 \%$ & $1.4 \%$ & $1.1 \%$ & the average \\
\hline
\end{tabular}

Source: Prepared by the researcher based on the statistical tables of the Statistics Department in the General Directorate of Educational Planning / Iraqi Ministry of Education

It is clear from the results of the Mann Whitney test that the $\mathrm{z}$ value is equal to (2.309-) and the level of significance equals (0.021) so we accept the hypothesis that there are statistically significant differences in the proportion of students in private schools at a level of significance $(\alpha<0.05)$ between the central and administrative decentralization periods. 


\section{Eighth: Analysis of the success rates of primary education}

By noting the approved figures in table (8) for the indicator (primary success rate) in primary schools (government, private and religious) we note the following:

Table (8) Analysis of primary school success rates

\begin{tabular}{|c|c|c|c|c|c|c|c|c|c|}
\hline \multirow[b]{2}{*}{ Average } & \multicolumn{3}{|c|}{ school year } & \multirow[b]{2}{*}{ Average } & \multicolumn{4}{|c|}{ school year } & \multirow[b]{2}{*}{ Governorate } \\
\hline & $18-17$ & 17 - 16 & $16-15$ & & $15-14$ & $14-13$ & $13-12$ & $12-11$ & \\
\hline $82.6 \%$ & $83.4 \%$ & $80.9 \%$ & $83.4 \%$ & $81.8 \%$ & $87.3 \%$ & $72.4 \%$ & $83.2 \%$ & $84.1 \%$ & Diyala \\
\hline $84.2 \%$ & $85.5 \%$ & $82.1 \%$ & $84.9 \%$ & $86.5 \%$ & $86.6 \%$ & $83.1 \%$ & $87.2 \%$ & $89.0 \%$ & Baghdad \\
\hline $79.8 \%$ & $80.8 \%$ & $81.3 \%$ & $77.4 \%$ & $82.5 \%$ & $80.2 \%$ & $82.5 \%$ & $82.7 \%$ & $84.5 \%$ & Babylon \\
\hline $75.9 \%$ & $77.5 \%$ & $75.9 \%$ & $74.3 \%$ & $80.2 \%$ & $77.3 \%$ & $78.1 \%$ & $82.2 \%$ & $83.3 \%$ & Karbala \\
\hline $78.8 \%$ & $80.2 \%$ & $78.9 \%$ & $77.4 \%$ & $83.5 \%$ & $80.0 \%$ & $80.6 \%$ & $86.8 \%$ & $86.4 \%$ & Najaf \\
\hline $83.9 \%$ & $84.5 \%$ & $84.3 \%$ & $82.9 \%$ & $88.5 \%$ & $83.6 \%$ & $82.3 \%$ & $93.1 \%$ & $94.8 \%$ & Qadisiyah \\
\hline $80.0 \%$ & $81.5 \%$ & $77.9 \%$ & $80.7 \%$ & $82.9 \%$ & $80.3 \%$ & $82.6 \%$ & $85.3 \%$ & $83.4 \%$ & Mouthana \\
\hline $79.8 \%$ & $81.9 \%$ & $78.7 \%$ & $78.7 \%$ & $83.9 \%$ & $79.2 \%$ & $80.0 \%$ & $81.5 \%$ & $94.8 \%$ & Wasit \\
\hline $82.9 \%$ & $83.8 \%$ & $82.2 \%$ & $82.6 \%$ & $89.6 \%$ & $82.6 \%$ & $80.9 \%$ & $97.1 \%$ & $97.9 \%$ & Dhi Qar \\
\hline $84.4 \%$ & $85.3 \%$ & $81.7 \%$ & $86.2 \%$ & $86.9 \%$ & $84.2 \%$ & $84.4 \%$ & $91.1 \%$ & $87.9 \%$ & Maysan \\
\hline $83.9 \%$ & $86.2 \%$ & $81.9 \%$ & $83.5 \%$ & $83.4 \%$ & $85.9 \%$ & $83.5 \%$ & $82.8 \%$ & $81.5 \%$ & Basra \\
\hline $81.5 \%$ & $82.8 \%$ & $80.5 \%$ & $81.1 \%$ & $84.5 \%$ & $82.5 \%$ & $80.9 \%$ & $86.6 \%$ & 88.0\% & the average \\
\hline
\end{tabular}

Source: Prepared by the researcher based on the statistical tables of the Statistics Department in the General Directorate of Educational Planning / Iraqi Ministry of Education

It is clear from the results of the Mann Whitney test that the value of $\mathrm{Z}$ is equal to (0) and the level of significance equalto (1) so we accept the nihilistic hypothesis that there are no statistically significant differences in the success rates of primary education at the level of significance $(\alpha<0.05)$ between the central and administrative decentralization periods. 


\section{Ninth: Analysis of the success rates of the secondary school}

By noting the approved figures in table (9) for the indicator (high school pass rate) in schools (public, private and religious) we note the following:

\begin{tabular}{|c|c|c|c|c|c|c|c|c|c|}
\hline \multirow[b]{2}{*}{ Average } & \multicolumn{3}{|c|}{ school year } & \multirow[b]{2}{*}{ Average } & \multicolumn{4}{|c|}{ school year } & \multirow[b]{2}{*}{ Governorate } \\
\hline & $18-17$ & $17-16$ & $16-15$ & & $15-14$ & $14-13$ & $13-12$ & $12-11$ & \\
\hline $71.6 \%$ & $70.6 \%$ & $70.9 \%$ & $73.3 \%$ & $75.2 \%$ & $75.8 \%$ & $68.9 \%$ & $82.5 \%$ & $73.4 \%$ & Diyala \\
\hline $65.8 \%$ & $68.3 \%$ & $65.9 \%$ & $63.2 \%$ & $71.5 \%$ & $65.1 \%$ & $68.1 \%$ & $78.5 \%$ & $74.4 \%$ & Baghdad \\
\hline $69.1 \%$ & $72.2 \%$ & $70.8 \%$ & $64.3 \%$ & $76.0 \%$ & $73.7 \%$ & $71.7 \%$ & $80.4 \%$ & $78.1 \%$ & Babylon \\
\hline $67.8 \%$ & $68.5 \%$ & $68.7 \%$ & $66.2 \%$ & $73.6 \%$ & $65.9 \%$ & $70.5 \%$ & $79.2 \%$ & $78.6 \%$ & Karbala \\
\hline $67.3 \%$ & $69.7 \%$ & $68.6 \%$ & $63.6 \%$ & $72.9 \%$ & $66.0 \%$ & $69.0 \%$ & $78.2 \%$ & $78.2 \%$ & Najaf \\
\hline $69.4 \%$ & $69.7 \%$ & $69.6 \%$ & $69.0 \%$ & $77.9 \%$ & $67.4 \%$ & $69.0 \%$ & $90.3 \%$ & $85.0 \%$ & Qadisiyah \\
\hline $64.6 \%$ & $65.5 \%$ & $64.2 \%$ & $64.0 \%$ & $70.1 \%$ & $62.6 \%$ & $67.8 \%$ & $77.6 \%$ & $72.4 \%$ & Mouthana \\
\hline $71.2 \%$ & $73.0 \%$ & $71.9 \%$ & $68.8 \%$ & $73.6 \%$ & $67.2 \%$ & $70.6 \%$ & $80.4 \%$ & $76.1 \%$ & Wasit \\
\hline $70.8 \%$ & $72.0 \%$ & $71.8 \%$ & $68.5 \%$ & $77.4 \%$ & $67.3 \%$ & $72.3 \%$ & $87.8 \%$ & $82.1 \%$ & Dhi Qar \\
\hline $70.3 \%$ & $68.3 \%$ & $70.4 \%$ & $72.2 \%$ & $81.5 \%$ & $80.0 \%$ & $76.9 \%$ & $89.0 \%$ & $80.0 \%$ & Maysan \\
\hline $64.0 \%$ & $68.4 \%$ & $63.0 \%$ & $60.6 \%$ & $65.6 \%$ & $65.1 \%$ & $65.2 \%$ & $68.3 \%$ & $63.9 \%$ & Basra \\
\hline $68.4 \%$ & $69.7 \%$ & $68.7 \%$ & $66.7 \%$ & $74.1 \%$ & $68.7 \%$ & $70.0 \%$ & $81.1 \%$ & $76.6 \%$ & the average \\
\hline
\end{tabular}

Source: Prepared by the researcher based on the statistical tables of the Statistics Department in the General

Directorate of Educational Planning / Iraqi Ministry of Education

It is clear from the results of the Mann Whitney test that the value of $\mathrm{Z}$ is equal to (0) and the level of significance equalto (1) so we accept the nihilistic hypothesis that there are no statistically significant differences in the success rates of secondary education at the level of significance $(\alpha<0.05)$ between the central and administrative decentralization periods . 


\section{CONCLUSIONS}

The mann Whitney test showed that there were statistically significant differences in all educational indicators analyzed during the two periods before and after the transfer of powers, with the exception of the three indicators, namely the student rate on a school and the two levels of success in the primary and secondary stages, and these differences have negatively affected educational performance, thus the shift to the decentralized system and the transfer of powers between the Iraqi Ministry of Education and the provinces have negatively affected educational performance.

\section{REFERENCES}

1. Aguinis, Herman (2009). Performance Management, 2nd Edition, Upper Saddle River, NJ, Pearson Education Inc.

2. Naseer, Youssef (2005), Indicators of Information and Communication Technology in Education, Information Technology Center National, Amman,Jordan.

3. Al-Qahtani, Mushabab bin Ayed (2019), Performance Measurement and Management in the Governmental Sector in the Kingdom of Saudi Arabia, The Second Conference of Institutes of Public Administration and Administrative Development in the Countries of the Cooperation Council for the Gulf Cooperation Council, Riyadh.

4. Al-Ammari, Saleh (2019), Requirements for the Application of Indicators of the School Performance System, Journal of Educational and Psychological Research, King Khalid University, Issue 61, Volume 16, Saudi Arabia.

5. Paige, Michael(2005),Internationalization of Higher Education: Performance Assessment and Indicators, College of Education and Human Development, University of Minnesota.

6. UNHCR(2006),UNHCR Education Standards and Indicators Handbook 2006, http: www.unhcr.org ,UNHCR Education. 